\title{
Discovery of Two Critically Endangered Tree Species and Issues Related to Relic Forests of the Western Ghats
}

\author{
M.D. Subash Chandran, D.K. Mesta, G.R. Rao, Sameer Ali, K.V. Gururaja and T.V. Ramachandra* \\ Energy \& Wetlands Research Group, Centre for Ecological Sciences, Indian Institute of Science, Bangalore 560012 , \\ India
}

\begin{abstract}
Madhuca bourdillonii (Gamble) Lam. and Syzygium travancoricum Gamble, considered almost extinct but later found to be occurring in small numbers in their home range in Western Ghats, south of Palghat Gap, have been now discovered in some of the relic primeval evergreen forests of Uttara Kannada, over $700 \mathrm{~km}$ north. These relic forests also shelter scores of other rare endemic elements of flora and fauna. These findings highlight the need for making intensive efforts for locating more of such relic forests and documenting their biota. Also, biologists need to restrain from the tendencies of considering any novel occurrences of species away from their home ranges as new species, before ruling out the possibilities that these could be the relics of ancient populations or their morphological variants. Presence of relic forests does reveal the legacy of erstwhile contiguous forests, which is now fragmented due to rapid land use changes. Conservationists handling biodiversity hotspots should be able to distinguish between relics of primeval forests and advanced stages of secondary successions. Lack of such understanding will result in imperceptible extinctions of many endemic species.
\end{abstract}

Keywords: Madhuca bourdillonii, Syzygium travancoricum, critically endangered, relic forests, Myristica swamps, local extinction, Uttara Kannada, Western Ghats.

\section{INTRODUCTION}

The Western Ghats is one among the 34 global hotspots of biodiversity and it lies in the western part of peninsular India in a series of hills stretching over a distance of 1,600 $\mathrm{km}$ from north to south and covering an area of about $1,60,000$ sq.km. In the course of our ecological studies in the Uttara Kannada (formerly North Kanara) district of central Western Ghats, we came across two critically endangered tree species, far away from their home range much in the south. These trees viz., Madhuca bourdillonii (Gamble) Lam. and Syzygium travancoricum Gamble, were even considered almost extinct. Their rare presence in some of the relic evergreen forests of Uttara Kannada, over $700 \mathrm{~km}$ towards the north of their original home range, in southern Western Ghats, that too beyond the geographical barrier of the Palghat Gap, which halts the continuity of several sensitive endemics, throws up before us fresh questions regarding conventional approach to conservation, which has not given due merit to the ecological history of the region. These tree species occur in the vicinity of some of the Myristica swamps of the district, which are obviously part of the relic patches of primeval low altitude evergreen forests that survived human impacts to some degree. Historically, the overall forest disturbance in the Western Ghats increased in spatial extent as well as in intensity, during the post World war era, with the emphasis on industrialization and economic development. Forest based industries coupled with large scale hydroelectric projects and conversions of forest land for agriculture have contributed significantly in the decline of primeval forests. The Myristica swamps did not get enough attention until Chandran and Mesta [1] reported them

*Address correspondence to this author at the Energy \& Wetlands Research Group, Centre for Ecological Sciences, Indian Institute of Science, Bangalore 560 012, India, E-mail: cestvr@ces.iisc.ernet.in as highly threatened relics of primeval forests of the Western Ghats. These swamps have high watershed value and are associated with perennial water courses. They also act as a treasure trove of endemic plants and animals of ancient lineage. These swamps are dominated by species of Myristicaceae (nutmeg family), one of the most ancient families of flowering plants. Myristica fatua var. magnifica (Bedd) Sinclair and Gymnacranthera canarica (King) Warburg, are tree species exclusive to the swamps. Recent discovery of Semecarpus kathalekanensis, an altogether new tree species of the mango family Anacardiaceae [2], in these swamps has created ripples in the conservation circles.

The micro-heterogeneity of these relic evergreen forests has several more endemic and interesting plant species, which include the trees Dipterocarpus indicus, Mastixia arborea, Agrostystachys longifolia and Myristica malabarica (Fig. 1); an undergrowth palm Pinanga dicksonii, a species of pepper Piper hookerii, a tree fern Cyathea nilgirica, etc. Lion-tailed macaque, an endemic endangered primate of the Western Ghats, has its northern-most range in the relic evergreen forests of southern Uttara Kannada, which also often harbour Myristica swamps. In addition are several other rare endemic animal species, which include amphibian genera like Nyctibatrachus and Micrixalus. The Myristica swamps of southern Uttara Kannada are found to harbour 29 species of amphibians of which 19 are Western Ghat endemics. Birds like Wyanad laughing thrush and Malabar pied hornbill associated with these swamp forests are also endemics. Phylloneura westersmanii, a damselfly of endemic monospecific genus Phylloneura was recently found in Myristica swamps of Siddapur $\left(14.5^{\circ} \mathrm{N}\right)$, the northern range of which was earlier considered to be Coorg $\left(12^{\circ} \mathrm{N}\right)$ district [3].

The Myristica swamps, which are sure indicators of relics of primeval forests of the Western Ghats, today occur in iso- 
lated patches; the southern-most swamps are found in Travancore region and the northern-most occur in Goa. Due to ever increasing human impacts, over the last few centuries, most of the primeval forests have given way to secondary forests, savannas, monoculture tree plantations, cash crops such as tea, coffee and rubber, rice fields, arecanut gardens, etc [4,5]. In addition, developmental projects such as hydel, and nuclear power plants, mining, etc., have mushroomed especially during the post-independence period. Nevertheless, the remains of numerous ancient sacred groves, specially preserved pepper forests of the past and many forest patches with difficult approach are serving as repositories of the endemic biodiversity of Western Ghats. Recent study of Western Ghats using WiFs (wide field sensor with spatial resolution of $70 \mathrm{~m}$ ) remote sensing data mapped certain unique evergreen forest patches, which coincided with Myristica swamps, Ochlandra reed ecosystems and Nagea wallichiana facies [6], which are obviously relics of primary evergreen forests.

Myristica swamps are considered as priceless possessions for evolutionary biology. The swamp, with its entanglement of aerial roots, and canopy of dark green large leaves, and high degree of endemism, is doubtlessly, the relic of one of the most primeval ecosystems of the Western Ghats. As much remained undone regarding the diversity and ecology of these swamps, they are considered "virtually live museum of ancient life of great interest to biologists" $[1,4]$. With the presumption that the Myristica swamps and their immediate surroundings, studded with Dipterocarpus trees (Fig. 1), could shed some light on the nature of the primeval low altitude evergreen forests of Uttara Kannada district, we began surveying these forest relics more systematically. Our search resulted in the discovery of two critically endangered tree species viz., Madhuca bourdillonii (Gamble) Lam. and Syzygium travancoricum (Gamble). We consider the occurrence of these species in Uttara Kannada as very significant due to the following reasons:

- These species were originally reported only from Travancore region [7].

- They were feared to be extinct according to the Red Data Book of Indian Plants [8,9].

- Subsequent investigations revealed their rare presence in southern Western Ghats, but only towards the south of the Palghat Gap [10,11].

- The Myristica swamps near which we found these species had the status of kan forests. The kans were safety forests cum sacred groves during the pre-colonial times [12].

\section{Madhuca bourdillonii (Gamble) Lam.}

Bourdillon [7], the discoverer of this species in Travancore during 1894-95 described it as a "rare tree of medium size occurring in the Ariankavu and Shenduruny valleys, but not seen elsewhere". Gamble [13], quoting Bourdillon, also described it in the Flora of the Presidency of Madras (vol.2). The Red Data Book of Indian Plants considered its status as "possibly extinct", since the species was not collected after Bourdillon's observation. The book states [9], "Indiscriminate and steady destruction of its natural habitats, compounded by selective felling of Madhuca trees in the past for their purported all round value, accounts for the present day state of scarcity in the Western Ghats region". Sasidharan and Sivarajan [10] found this species in the forests of Thrissur district $\left(10.66^{\circ} \mathrm{N}, 76.25^{\circ} \mathrm{E}\right)$, to the north of the type localities. Later, it was also found in its type localities namely Arainkavu and Shenduruny valley and was reported [11] as "rare".

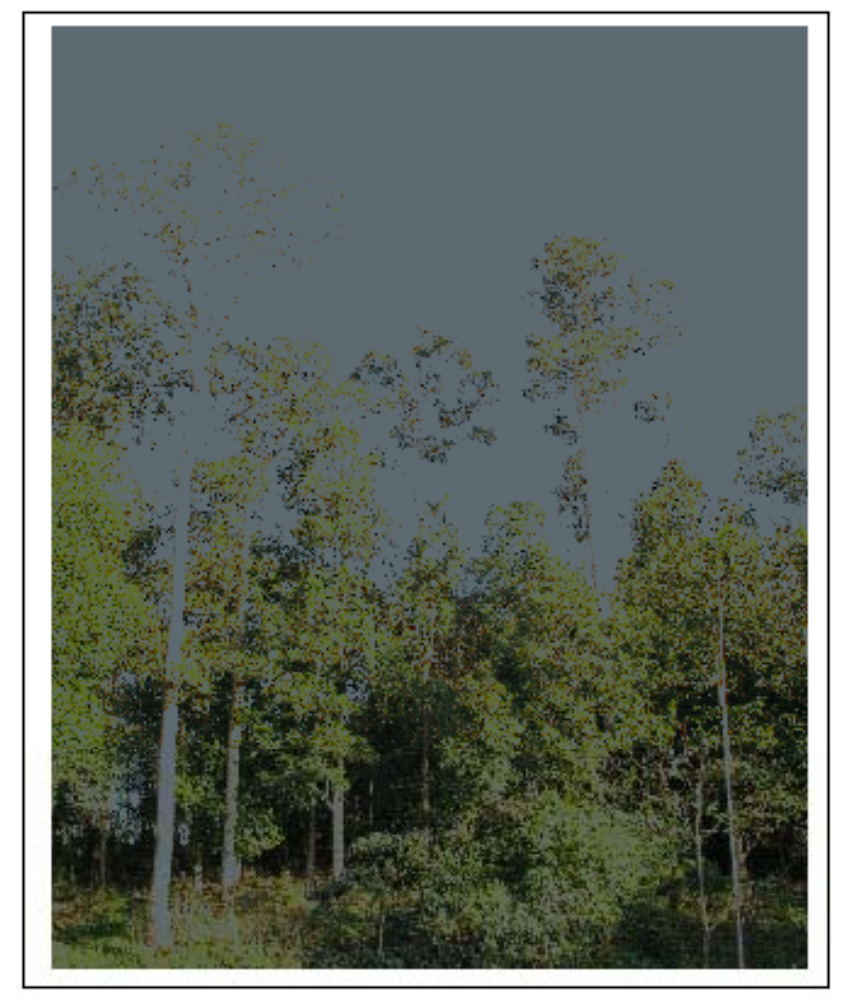

Fig. (1). A relic forest with Dipterocarpus indicus.

\section{OCCURRENCE OF M. BOURDILLONII IN UTTARA KANNADA}

Notably all the findings of the species hitherto were towards the south of Palghat Gap, until we came across a rare population in Ankola taluk $\left(14.7^{\circ} \mathrm{N}\right)$, of Uttara Kannada district, in the central Western Ghats. Our find extends the northern limit of the species by about $500 \mathrm{~km}$; but more significantly, this is the first report of the species from north of the Palghat Gap. Fig. (2) depicts these locations along with the earlier sightings. There were only 13 trees of this critically endangered species dispersed within a stretch of evergreen forests. Three of them exceeded $30 \mathrm{~m}$ in height and were about $2 \mathrm{~m}$ in girth while others were much smaller. These trees occurred in a relic forest characterised by a Myristica swamp and endemic trees such as Aglaia anamallayana, Dipterocarpus indicus, Garcinia talbotii, Holigarna spp., Gymnacranthera canarica, Knema attenuata, Myristica malabarica, etc. Incidentally, this site is also a northward extension for $D$. indicus by about $30 \mathrm{~km}$, from the previous report [14].

\section{DESCRIPTION OF M. BOURDILLONII}

Madhuca bourdillonii is a medium to large tree exceeding $30 \mathrm{~m}$ height at maturity (Fig. 3a). Though described as an evergreen [9], it has a brief period of leaf-fall, which is not strictly season bound. Flowering is simultaneous with leaf-fall and new flush that follows is mingled with late 




Fig. (2). Distribution map of Madhuca bourdillonii and Syzygium travancoricum in the South-west India.

blooming flowers and early fruits. The trees have grayish brown, longitudinally fissured and flaky bark with a pinkish interior (Fig. 3b). The plant parts have milky latex like other species of Madhuca. Young shoots, including young leaves, are densely covered with brownish-orange, wooly hairs. In the mature leaves the undersurface of veins retains the hairs. In other related species like $M$. longifolia var. longifolia and $M$. longifolia var. latifolia and $M$. neriifolia mature leaves are not hairy. The leaves are simple (Fig. 3a) reaching dimensions of $20-32 \times 6-10 \mathrm{~cm}$ and crowded towards the tips of branchlets. They have conical base and bluntly acute to narrowing tips. In having 20-25 pairs of lateral nerves $M$. bourdillonii stands apart from its close associates $M$. longifolia var. longifolia (10-12 pairs) and M. longifolia var. latifolia (10-14 pairs). Flowers appear in dense clusters (Fig. 3c) from the axils of fallen leaves or of older leaves that are about to fall. When the tree is in full bloom, clusters of young leaves appear from the tips of branchlets. The stalks of flowers, 1.5-2 cm long, are also covered with dense hairs. Sepals are 4, ovate and hairy outside. Corolla consists of 12 united petals. Stamens are often twice the number of petals, in two whorls. The anther is tipped with a narrow outgrowth.

Genus Madhuca produces berries (Fig. 3d) with one to few seeds. Globose fruit is a key distinguishing character of $M$. bourdillonii. Madhuca longifolia var. latifolia has globose fruit, with oblique apex [15] and M. longifolia var. longifolia has ovoid fruit. Both these varieties have 1 or 2 seeds whereas $M$. bourdillonii has 2-3 seeds (Fig. 3e). Table 1 compares the various Madhuca spp. of South India.

\section{Syzygium travancoricum Gamble}

The tree was first discovered in the swampy lowlands (altitude $<65 \mathrm{~m}$ ) of Travancore by Bourdillon in 1894. Gamble [17] described it in 1918 in the Kew Bulletin and in the Flora of the Presidency of Madras in 1919. The Red Data Book of Indian Plants [8], quoting Nair and Mohanan [18], states: "Apparently no tree is surviving in the type locality. Recently only four trees have been spotted in a sacred grove of Aikad in Quilon district". However, Sasidharan [11] rediscovered it in the type locality - Shenduruny Wildlife Sanctuary. According to him this species, endemic to south- ern Western Ghats of Kerala, is associated with the Myristica swamp forests.

\section{OCCURRENCE OF S. TRAVANCORICUMIN UTTARA KANNADA}

We came across about 35 trees of this species in association with some of the Myristica swamps of Siddapur taluk (14.4 ${ }^{\circ}$ $\mathrm{N})$. The tree occurred along with several other Western Ghat endemics such as Aglaia anamallayana, Calophyllum apetalum, Diospyros paniculata, D. pruriens, Dipterocarpus indicus, Gymnocranthera canarica, Holigarna grahamii, Hydnocarpus pentandra, Hopea ponga, Mastixia arborea, Myristica fatua var. magnifica, Pinanga dicksonii, etc. In Ankola taluk, a single tree was observed in a Myristica swamp (Fig. 4a). Some bushy forms, obviously coppice shoots (Fig. 4b), occurred close to it. The occurrence of the species in Ankola is a range extension for it by about 700 $\mathrm{km}$ from Travancore (Fig. 2), where it was considered to be restricted.

\section{DESCRIPTION OF S. TRAVANCORICUM}

Gamble [17] described the species as medium sized or large tree, while, Sasidharan [11] found only small trees. The largest trees that we observed were about $30 \mathrm{~m}$ in height. Two of the trees had girths of 253 and $254 \mathrm{~cm}$ respectively. The older trees have buttresses at the base. The young branchlets are 4-angled; in the saplings the angles are winged. Stream side trees have floating water roots, an adaptation to swampy habitat (Fig. 4c). Leaves are simple, opposite, ovate and bluntly acute towards the tip. The leaf base is shortly decurrent (continued) on the $2 \mathrm{~cm}$ long petiole. Leaf measures $9-18 \mathrm{~cm}$ in length and $6-9 \mathrm{~cm}$ in breadth. It has $12-$ 15 pairs of lateral nerves. Flowers occur in the axils of leaves in corymbose cymes of 5-8 cm long (Fig. 4d). They are very small, only $3 \mathrm{~mm}$ across. The white petals form a calyptra (cap) in the bud enclosing the stamens. Fruits $0.7-1 \mathrm{~cm}$ across, purplish to maroon-red (Fig. 4e). Fruits ripen in MayJune. None of the floras provide the description of the fruit although it is sketched in the flora of Shenduruny Wildlife Sanctuary [11].

\section{THE VALUE OF FOREST PATCHES}

The impact of forest fragmentation is severe in the tropics, where biodiversity is rich, and human populations are rapidly growing. Studies show decline of forest birds [19], large wide ranging species [20] and more specifically specialised species [21] that require unique habitat for survival. It also influences distribution and availability of spatial resources, forest connectivity and edge characteristics, which are important for species persistence [22-24]. Also, trees in the fragmented habitats have higher annual tree mortality rates due to vagaries of wind [25]. Fragmentation effects cascade through the community, modifying inter-specific interactions, providing predator or competitive release, altering social relationships and movement of individuals, exacerbating edge effects, modifying nutrient flows, and potentially even affecting the composition of local population [26]. In many tropical regions, rain forest is restricted to small ( $<100 \mathrm{ha})$, isolated fragments. The conservation of such smaller fragments had not merited much attention till recent years. In regions like Western Ghats, there is not much hope for creation of more and more large-sized protected area systems due to social, economic and political 

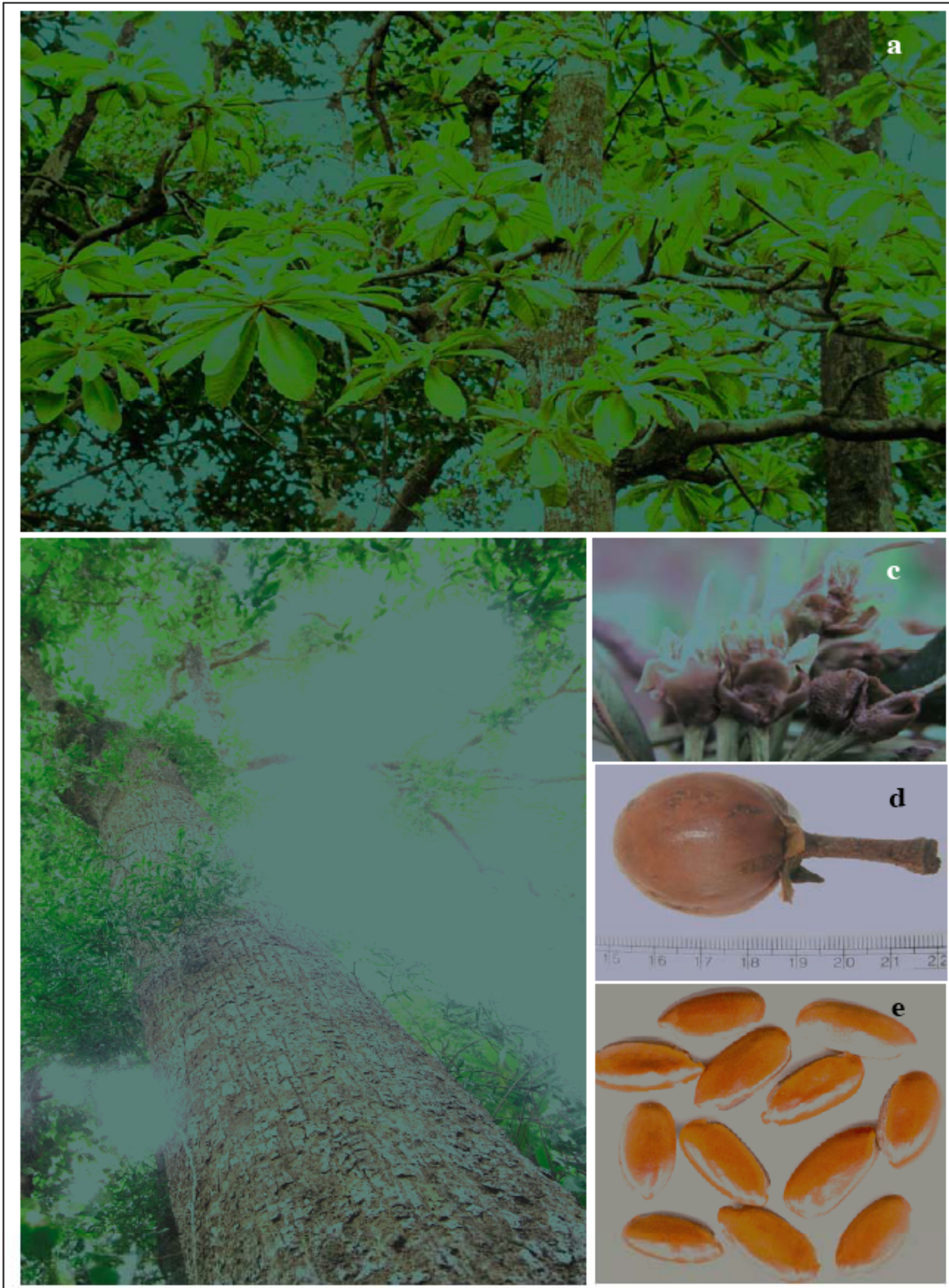

Fig. (3). a) Madhuca bourdillonii in flush; b) An old tree of $M$. bourdillonii - showing fissured and flaky bark; c) flower; d) fruit and e) seeds. 
Table 1. Comparative Morphology of Different Species of Madhuca

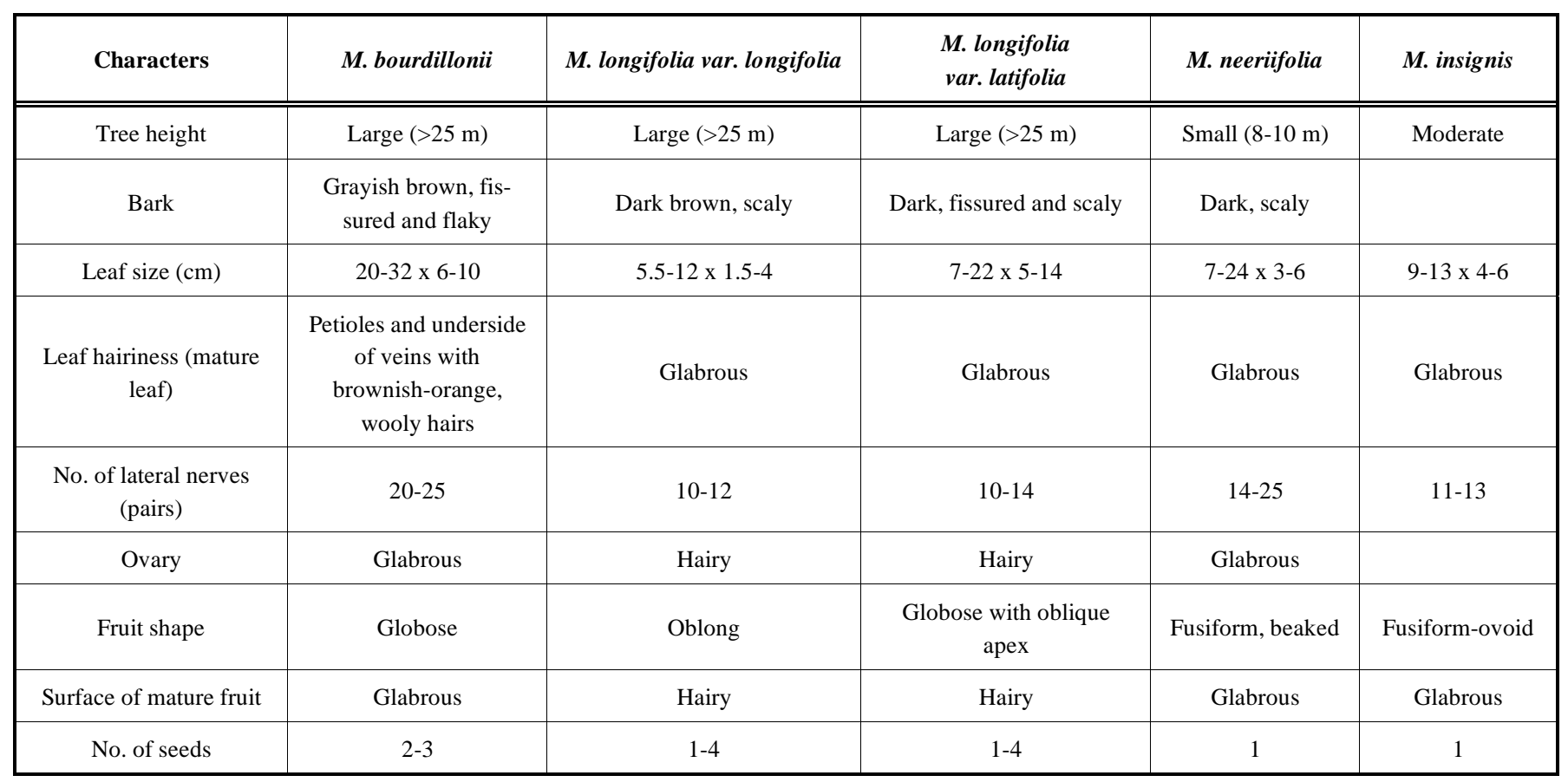

Table based on observations by authors and floras of Bourdillon [7], Gamble [13], Saldanha [15], Sasidharan and Sivarajan [10], Sasidharan [11], Bhat [16].

constraints [27, 28]. Also, the presence of roads, power lines and substantial nearby human population has prevented the recovery [29]. 'Forest patches' include a diversity of habitats which are in close proximity forming a mosaic, or even in isolation like a sacred forest in the middle of a village or small town. Investigations into the ecological history of the Western Ghats reveal that the forests here, especially of altitudes below $1000 \mathrm{~m}$, constitute a mosaic of patches of varied nature and ages.

In the Uttara Kannada district of central Western Ghats, where we conducted our present study, this landscape mosaic, according to traditional pre and early colonial land use, typically consisted of sacred forests (kans or devarabana), ordinary forests (kadu or adavi), shifting cultivation areas (kumri or hakkalu), leaf manure forests (betta), grazing lands (bena), etc., in addition to lands under permanent agriculture and horticulture. Such traditional mosaic within it might contain streams, ponds, waterfalls and rivers, gorges and steeps and rocky pinnacles, each with its own characteristic species composition [12, 27, 28, 30]. Sacred forest fragments are shelters of biodiversity, meeting the needs of non-timber forest produce requirement and are best protected by local communities [31]. The lower altitudes of pre-historical Western Ghats, before the beginning of shifting cultivation, around 3,000 years ago, would have been covered with pristine ecosystems, more or less untrammeled by man, except by hunter-gatherers, who seldom if at all, indulged in forest alterations. Especially due to the heavy rainfall, western facing portions of the mountains would have been covered with tropical evergreen forests, laced with water courses and swamps [24,27]. Earlier studies in the Western Ghats also showed that remnants foster successional processes in natural restoration of rainforests [32]. Shifting cultivation was a major activity of forest dwelling tribals, throughout the Western Ghats, sparing only the higher altitudes. Carried out through centuries this might have altered substantially the primary evergreen forests. In sparsely populated interior places of South Indian Western Ghats, the forests would regrow and through time get back most of the original elements of the flora barring a few, as the fallow period was long (sometimes the tribes never returned to the original areas). As fire was an important factor in shifting cultivation, it may be that hygrophilous endemic tree species such as Dipterocarpus indicus and Vateria indica, failed to regenerate on slash and burn areas, but survived in protected areas like the sacred forests. The same could be true of Madhuca bourdillonii and Syzygium travancoricum (Fig. 5).

\section{DISCUSSION}

Forest history of Uttara Kannada reveals that shifting cultivation was a decisive force that altered the primary forests substantially, creating vast stretches of secondary forests. The early agricultural communities, however, left behind a great legacy of sacred forests (kans) in Uttara Kannada and other adjoining districts. Many of these kans to this day are relics of the primary forests of the Western Ghats and are centers of endemism for both plants and animals. Myristica swamps are associated with some of these sacred forests $[1,12,27,28]$. These relics lost their special identity as sacred forests and got merged with the state reserve forests during the British administration [27]. Subsequently, they were subjected to commercial timber harvests, tree monocultures, etc. In many places, the kans were cut down for expansion of cultivation or converted into leaf manure forests or subjected to other kinds of human impacts [28, 29].

Our finding of Dipterocarpus in Ankola $\left(14.7^{\circ} \mathrm{N}\right)$ goes to substantiate Caratini et al. [33], who have reported the presence of its pollen in marine core samples close to Kali River estuary $\left(14.8^{\circ} \mathrm{N}\right)$. This is incidentally range extension of present distribution of Dipterocarpus towards north by 30 


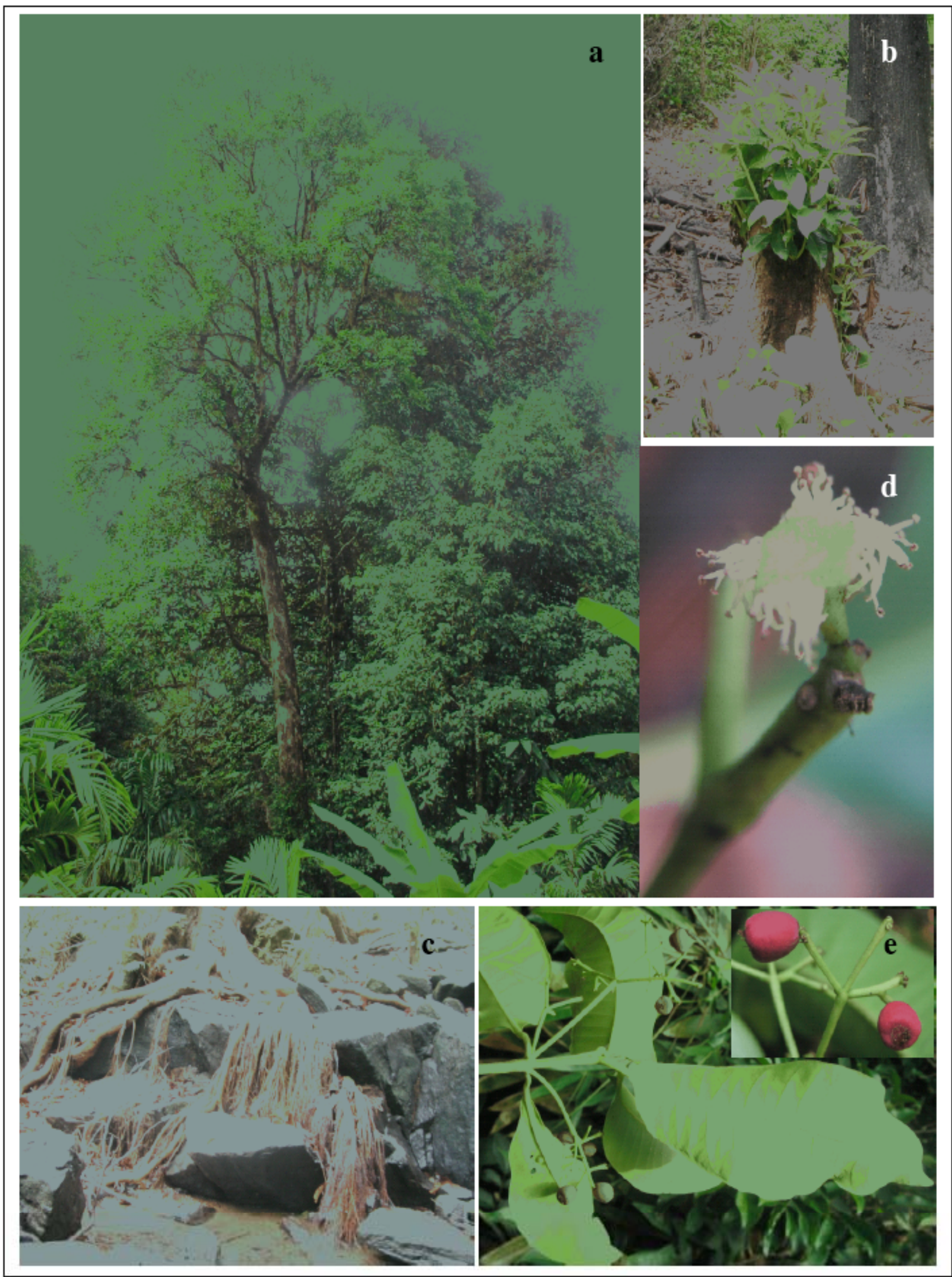

Fig. (4). a) Syzygium travancoricum - habit; b) coppicing stump; c) floating water roots; d) a single flower and e) twig with fruits. 


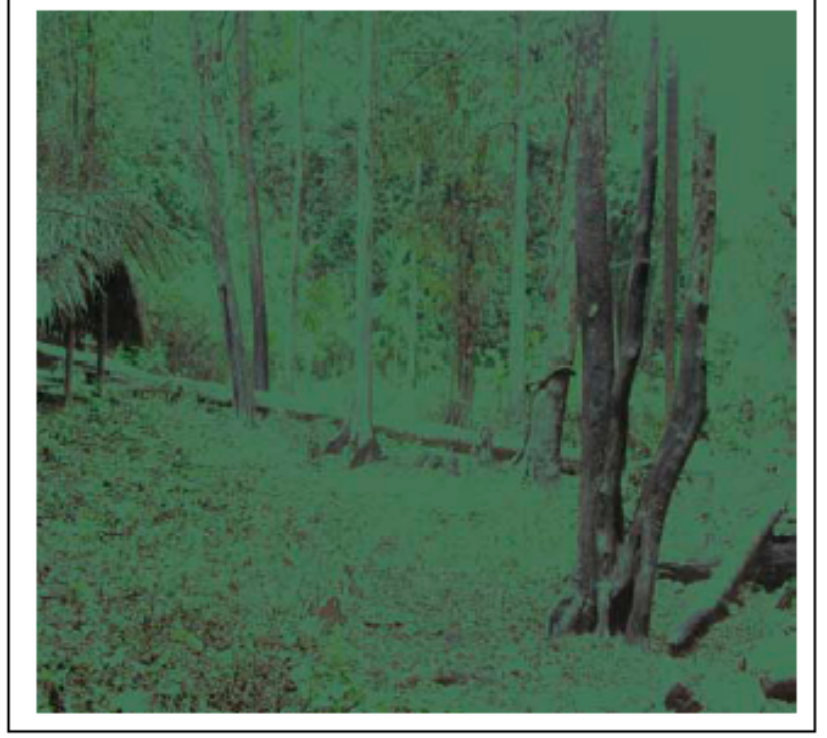

Fig. (5). The habitat of Syzygium travancoricum - under threat from encroachment.

$\mathrm{km}$. The Dipterocarpus patch in Ankola was obviously part of a sacred kan forest. A small Myristica swamp is also associated with it. Same could be stated about Syzygium travancoricum, a stately tree, thought to be extinct once, but rediscovered later, only in southern Western Ghats. Our findings of this critically endangered tree in Siddapur of Uttara Kannada and a single individual in Ankola, in forest patches of ancient antiquity, is very significant. The Siddapur relic forests are also home to recently discovered new tree species Semecarpus kathalekanensis [2]. However, biologists should restrain themselves from the general tendency of naming any apparent novel occurrences of plants or animals that they might come across in relic forests as new species; these could as well be the relics of ancient populations or their morphological variants.

The occurrence of Madhuca bourdillonii and Syzygium travancoricum in Uttara Kannada forests of central Western Ghats, along with Myristica swamps and Dipterocarpus, clearly goes to prove that low altitude climax evergreen forests with the entire gamut of endemic species of flora and fauna, had more northern ranges for their distribution. Their present day disjunct distribution is largely on account of human impacts on the primeval forests, which have been largely wiped out. Several authors also consider that the current discontinuity of some faunal species in India, might represent relics of a former continuous distribution [34-37]. Karanth [38] considers climatic change and deforestation might be the major causes for present day disjunct distribution and aggregation of the endemic and endangered primate lion-tailed macaque (Macaca silenus) in the relics of wet evergreen forest patches of the South Indian Western Ghats.

The view is strengthening among the conservationists about the importance of protecting also smaller patches of forests in the tropics that lie outside large reserves as a substantial number of forest species can persist for decades in fragmented forest [6,38-40]. Inevitably, small fragments will become the last refuges of many rainforest species that are on the brink of extinction, despite the proneness of such populations suffering from depressed reproductive outputs
[41]. It is in some such fragmented forests that we have observed the critically endangered species Madhuca bourdillonii and Syzygium travancoricum.

What is of grave concern for conservationists is the casual attitude with which the Western Ghat forests are managed, nearly oblivious of their ecological history. Bulk of the primeval forest fragments, in whose conservation the precolonial farmers appear to have played key role have perished during the period of modern forestry, whose foundations were laid by the British. Foresters and ecologists should be able to distinguish between relics of primeval forests and advanced stages of secondary successions. Lack of this perception would result in the silent extinctions of scores of endemic species. Madhuca bourdillonii in Uttara Kannada is on the verge of extinction on account of unsatisfactory reproduction as well as human and predatory pressures. We are hopeful that more such relic patches with their valuable biota might be in existence in between Travancore and Uttara Kannada.

\section{ACKNOWLEDGEMENTS}

We are grateful to the Ministry of Environment and Forests, Government of India and Indian Institute of Science for the sustained financial and infrastructure support to carry out ecological research in the Western Ghats. We thank Vishnu D Mukri and Shrikanth Naik for assistance during field investigations.

\section{REFERENCES}

[1] Chandran MDS, Mesta DK (2001) On the conservation of the Myristica swamps of the Western Ghats. In: Forest Genetic Resources: Status, Threats, and Conservation Strategies. (eds. Uma Shaanker, R., Ganeshaiah, K.N., and Bawa, K.S.). Oxford and IBH, New Delhi. pp. 1-19.

[2] Dasappa, Swaminath MH (2000) A new species of Semecarpus (Anacardiaceae)_ from the Myristica swamps of Western Ghats of North Kanara, Karnataka, India. Indian Forester 126: 78-82.

[3] Subramanian KA (2007) Endemic Odonates of the Western Ghats: Habitat distribution and conservation. In: Odonata-biology of dragonflies. (ed. Tyagi). Scientific Publishers, Jodhpur, India. pp. 257271.

[4] Chandran MDS, Mesta DK (2005) Myristica swamps. Sahyadri ENews, Issue 13, http://wgbis.ces.iisc.ernet.in/biodiversity/sahyadri_ enews/ newsletter/issue13/index.htm accessed on 25 May 2007.

[5] Gururaja KV, Aravind NA, Sameer Ali, Ramachandra TV, Velavan TP, Krishna Kumar K, Aggarwal RK (2007) A new frog species from the central Western Ghats of India, and its phylogenetic status. Zool Sci 4: 525-534.

[6] Das A, Krishnaswamy J, Bawa KS, Kiran MC, Srinivas V, Kumar NS, Karanth KU (2006) Prioritisation of conservation areas in the Western Ghats, India. Biol Conserv 133: 16-31

[7] Bourdillon TF (1908) The Forest Trees of Travancore. The Travancore Government Press, Trivandrum. pp. 238-239.

[8] Nayar MP, Sastry ARK (1987) Red data book of Indian Plants, Vol. I. Botanical Survey of India, Calcutta. pp. 217-218.

[9] Nayar MP, Sastry ARK (1990) Red data book of Indian Plants, Vol. III. Botanical Survey of India, Calcutta. pp. 243-244.

[10] Sasidharan N, Sivarajan VV (1996) Flowering Plants of Thrissur Forests. Scientific Publishers, Jodhpur. pp. 265-266.

[11] Sasidharan N (1997) Studies on the Flora of Shenduruny Wildlife Sanctuary with Emphesis on Endemic species. Kerala Forest Research Institute Research Report No. 128. pp. 125-126.

[12] Chandran MDS, Gadgil M (1993) Kans - safety forests of Uttara Kannada. In: Proceedings of the IUFRO Forest History Group Meeting on Peasant Forestry. (ed. Brandl, M.). Forstliche Versuchs-und Forschungsanstalt, Freiburg. pp. 49-57.

[13] Gamble JS (1921) Flora of the Presidency of Madras. Adlard and Son, Ltd., London. Vol. 2. pp. 762-763. 
[14] Pascal JP, Shyam Sundar S, Meher-Homji VM (1984) Forest Map of South India: Belgaum-Dharwad. French Institute, Pondicherry.

[15] Saldanha CJ (1984) Flora of Karnataka. Oxford and IBH Publishing Co., New Delhi. Vol. 1. pp. 535.

[16] Bhat KG (2003) Flora of Udupi. Indian Naturalist, Udupi. pp. 913.

[17] Gamble JS (1935) Flora of the Presidency of Madras, Adlard and Son, Ltd., London, Vol. 1. pp. 477, 480.

[18] Nair NC, Mohanan CN (1981) On the rediscovery of four threatened species from the sacred groves of Kerala. J Econ Tax Bot 2, 233-235.

[19] Askins RA, Lynch JF, Greenberg R (1990) Population declines in migratory birds in eastern North America. Curr Ornithol 7, 1-57.

[20] Pelton M (1986) Habitat needs of black bears in the East In: Wilderness and natural areas in the eastern United States: A management challenge. (eds. Kulhavy D., Conner, R.). Stephen F. Austin Univ., Nacogdoches, Texas. pp. 49-53.

[21] Rosenberg KV, Raphael MG (1986) Effects of forest fragmentation in Douglas-fir forests. In: Wildlife 2000: Modeling habitat relationships of terrestrial vertebrates. (eds. Verner, J., Morrison, M.L. Ralph, C.J.). Univ. of Wisconsin Press, Madison, Wisconsin. pp. 263-272.

[22] Noss RF, Harris LD (1986) Nodes, networks and MUM's: Preserving diversity at all scales. Environ Manage 10, 299-309.

[23] Yahner RH (1988) Changes in wildlife communities near edges. Conserv Biol 2, 333-339.

[24] Sreekantha, Subash Chandran MD, Mesta DK, Rao GR, Gururaja KV, Ramachandra TV (2007) Fish Divirsity In Retation To Landscape and Vegetation in Central Western Ghats, India. Curr Sci 92, 1592-1603.

[25] Bierregaard RO, Jr Lovejoy TE, Kapos V, Augusto dos Santos A, Hutchings RW (1992) The biological dynamics of the tropical rainforest fragments, BioSci 42, 859-866.

[26] Debinski DM, Holt RD (2000) A survey and overview of habitat fragmentation experiments. Conserv Biol 14, 342-355.

[27] Chandran MDS (1997) On the ecological history of the Western Ghats. Curr Sci 73, 146-155.

[28] Chandran MDS (1997) Shifting cultivation, sacred groves and conflicts in colonial forest policy in the Western Ghats. In: Nature and the Orient: The Environmental History of South and Southeast Asia. (eds. Grove, R.H., Damodaran, V. and Sangwan, S.). Oxford University Press, New Delhi, pp. 674-707.
[29] Pomeroy M, Primack R, Rai SN (2003) Changes in four rain forests plots of the Western Ghats, India, 1939-93. Conserv Soc 1, 113-135

[30] Chandran MDS, Gadgil M (1998) Sacred groves and sacred trees of Uttara Kannada. In: Lifestyle and Ecology. (ed. Saraswati, B.). Indira Gandhi National Centre for the Arts and D.K. Printworld, New Delhi. pp. 85-138.

[31] Kokou K, Adjossou K, Kokutse AD (2007) Considering sacred and riverside forests in criteria and indicators of forest management in low wood producing countries: The case of Togo. Ecol Indicat doi:10.1016/j.ecolind.2006.11.008.

[32] Puyravaud JP, Dufour C, Aravajy S (2003) Rain forest expansion mediated by successional processes in vegetation thickets in the Western Ghats of India. J Biogeography 30, 1067-1080.

[33] Caratini C, Fontugne M, Pascal JP, Tissot C, Bentaleb I (1991) A major change at ca. $3500 \mathrm{BP}$ in the vegetation of the Western Ghats in North Kanara, Karnataka. Curr Sci 61, 669-672.

[34] Mani MS (1974) Biogeographical evolution in India. In: Ecological Biogeography of India. (ed. Mani, M.S.). Dr. W.S. Junk B.V. Publishers, The Hague. pp. 698-724.

[35] Ali S (1935) The ornithology of Travancore and Cochin. J Bombay Nat Hist Soc 37, 814-843.

[36] Daniel JC (2002) The Book of Indian Reptiles and Amphibians. Oxford University Press, Mumbai. pp. 248.

[37] Das I (2002) An Introduction to the Amphibians and Reptiles of Tropical Asia. Natural History Publications (Borneo), Kota Kinabalu. pp. 207.

[38] Karanth KP (2003) Evolution of disjunct distributions among wet zone species of the Indian subcontinent: testing various hypotheses using a phylogenetic approach. Curr Sci 85, 1276-1283.

[39] World Resources Institute, (1994) WRI/UNEP/UNDP. World Resources 1994-95. Oxford University Press, New York. pp. 83106.

[40] Schelhas J, Greenberg R (1996) The value of forest patches. In: Forest Patches in Tropical Landscapes. (eds. Schelhas, J. and Greenberg). Island Press, Washington D.C. pp. xv-xxxvi.

[41] Turner IM, Corlett RT (1996) The conservation value of small, isolated fragments of lowland tropical rain forest. TREE, 11, 330333.
Received: December 31, $2007 \quad$ Revised: January 29, $2008 \quad$ Accepted: January 30, 2008 